University of Nebraska - Lincoln

DigitalCommons@University of Nebraska - Lincoln

8-2009

\title{
Spiroadamantyl 1,2,4-trioxolane, 1,2,4-trioxane, and 1,2,4-trioxepane pairs: Relationship between peroxide bond iron(II) reactivity, heme alkylation efficiency, and antimalarial activity
}

\author{
Xiaofang Wang \\ University of Nebraska Medical Center \\ Darren J. Creek \\ Monash University, Parkville, Victoria, Australia \\ Charles E. Schiaffo \\ University of Nebraska-Lincoln \\ Yuxiang Dong \\ University of Nebraska Medical Center \\ Jacques Chollet \\ Swiss Tropical Institute, Basel \\ See next page for additional authors \\ Follow this and additional works at: https://digitalcommons.unl.edu/chemistrydussault \\ Part of the Chemistry Commons
}

Wang, Xiaofang; Creek, Darren J.; Schiaffo, Charles E.; Dong, Yuxiang; Chollet, Jacques; Scheurer, Christian; Wittlin, Segio; Charman, Susan A.; Dussault, Patrick; Wood, James K.; and Vennerstrom, Jonathan L., "Spiroadamantyl 1,2,4-trioxolane, 1,2,4-trioxane, and 1,2,4-trioxepane pairs: Relationship between peroxide bond iron(II) reactivity, heme alkylation efficiency, and antimalarial activity" (2009). Patrick Dussault Publications. 8.

https://digitalcommons.unl.edu/chemistrydussault/8

This Article is brought to you for free and open access by the Published Research - Department of Chemistry at DigitalCommons@University of Nebraska - Lincoln. It has been accepted for inclusion in Patrick Dussault Publications by an authorized administrator of DigitalCommons@University of Nebraska - Lincoln. 


\section{Authors}

Xiaofang Wang, Darren J. Creek, Charles E. Schiaffo, Yuxiang Dong, Jacques Chollet, Christian Scheurer, Segio Wittlin, Susan A. Charman, Patrick Dussault, James K. Wood, and Jonathan L. Vennerstrom 


\title{
Spiroadamantyl 1,2,4-trioxolane, 1,2,4-trioxane, and 1,2,4-trioxepane pairs: Relationship between peroxide bond iron(II) reactivity, heme alkylation efficiency, and antimalarial activity
}

\author{
Xiaofang Wang, ${ }^{1}$ Darren J. Creek, ${ }^{2}$ Charles E. Schiaffo, ${ }^{3}$ Yuxiang Dong, ${ }^{1}$ Jacques Chollet, ${ }^{4}$ \\ Christian Scheurer, ${ }^{4}$ Sergio Wittlin, ${ }^{4}$ Susan A. Charman, ${ }^{2}$ Patrick H. Dussault, ${ }^{3}$ \\ James K. Wood, ${ }^{5}$ and Jonathan L. Vennerstrom ${ }^{1}$ \\ 1. College of Pharmacy, University of Nebraska Medical Center, 986025 Nebraska Medical Center, Omaha, NE, USA \\ 2. Centre for Drug Candidate Optimisation, Monash Institute of Pharmaceutical Sciences, \\ Monash University (Parkville Campus), 381 Royal Parade, Parkville, Victoria 3052, Australia \\ 3. Department of Chemistry, University of Nebraska-Lincoln, Lincoln, NE, USA \\ 4. Swiss Tropical Institute, Socinstrasse 57, CH-4002 Basel, Switzerland \\ 5. Department of Chemistry, University of Nebraska at Omaha, Omaha, NE, USA \\ Corresponding author - J. L. Vennerstrom, tel 402 559-5362, fax 402 559-9543, email jvenners@unmc.edu
}

\begin{abstract}
These data suggest that iron(II) reactivity for a set of homologous spiroadamantyl 1,2,4-trioxolane, 1,2,4-trioxane, and 1,2,4-trioxepane peroxide heterocycles is a necessary, but insufficient, property of animalarial peroxides. Heme alkylation efficiency appears to give a more accurate prediction of antimalarial activity than $\mathrm{FeSO}_{4}$-mediated reaction rates, suggesting that antimalarial activity is not merely dependent on peroxide bond cleavage, but also on the ability of reactive intermediates to alkylate heme or other proximal targets.
\end{abstract}

Keywords: 1,2,4-trioxolane, 1,2,4-trioxane, 1,2,4-trioxepane, peroxide, antimalarial, artemisinin

The semisynthetic artemisinins rapidly reduce parasite burden and are particularly effective when used in a 3-day artemisinin combination treatment (ACT) regimen. ${ }^{1}$ One hypothesis $^{2-4}$ that accounts for the antimalarial specificity of artemisinin ${ }^{5}$ is that the peroxide bond undergoes reductive activation by heme released by parasite hemoglobin digestion to produce carbon-centered free radicals or carbocations that alkylate heme ${ }^{6}$ or parasite proteins. Although the 1,2,4-trioxane heterocycle in artemisinin (Figure 1) is the critical pharmacophore, its presence alone $^{7}$ is insufficient for high antimalarial activity as most synthetic 1,2,4-trioxanes are less active than artemisinin. ${ }^{8}$ The discovery ${ }^{9}$ of ozonide (1,2,4-trioxolane) drug development candidate OZ277 (arterolane) (Figure 1), now entering Phase III clinical trials in the form of an arterolane maleate + piperaquine phosphate combination, prompted us to investigate a set of structurally related 1,2,4-trioxolanes 1 , 1,2,4-trioxanes 2, and 1,2,4-trioxepanes $3^{10}$ (Figure 2) to better understand the relationship between peroxide bond iron(II) reactivity and antimalarial activity for these homologous peroxide heterocycles.
Trioxolanes $\mathbf{1 b}^{11}$ and $\mathbf{1 c}$ were obtained by Griesbaum coozonolysis $^{12}$ of the corresponding oxime ether/ketone ${ }^{13-14}$ pairs $4 / 5$ and $6 / 7$ in low yields (Scheme 1 ). Trioxolane 1a was similarly obtained as previously described. ${ }^{15}$

Trioxanes $\mathbf{2 b}$ and $\mathbf{2} \mathbf{c}$ were prepared as shown in Scheme 2. In the presence of catalytic $p$-toluenesulfonic acid (PTSA), $\mathbf{2 b}$ was readily formed by condensation of $\beta$-hydroperoxy alcohol $8^{16}$ with 5 . Attempts to perform the corresponding reaction of $\beta$-hydroperoxy alcohol $9^{16}$ with 5 provided only small quantities of trioxane $2 \mathrm{c}$ accompanied by a complex mixture

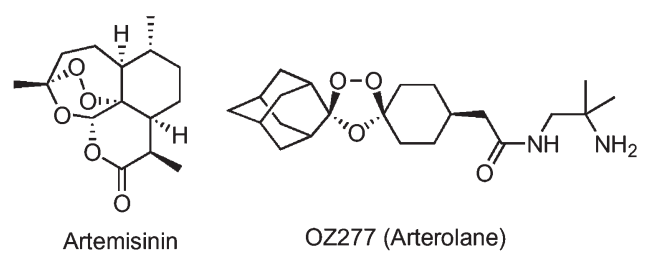

Figure 1. Artemisinin and OZ277. 


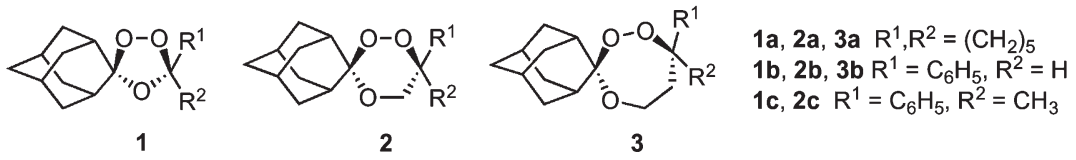

Figure 2. Trioxolanes $\mathbf{1}$, trioxanes $\mathbf{2}$, and trioxepanes $\mathbf{3}$.

of decomposition products. Characterization of the reaction products indicated that $\beta$-hydroperoxy alcohol 9 underwent acid-catalyzed O-O bond (pathway I) and C-O bond (pathway II) heterolysis followed by rearrangement. Formation of ketone 7 (pathway I) can be rationalized by a Grob-type fragmentation or by migration of the hydroxymethyl group. ${ }^{17}$ This contrasts with the phenyl migration seen in the acid-catalyzed decomposition of cumene hydroperoxide to form phenol and acetone. ${ }^{18}$ Aldehyde $\mathbf{1 1}$ may arise from the formation and rearrangement of a relatively stable benzylic tertiary carbocation in the transition state for fragmentation, with the co-generated hydrogen peroxide producing lactone 12 via an acid-catalyzed Baeyer-Villiger oxidation of adamantanone Thus, acid-catalyzed heterolytic peroxide bond fragmentation (pathway II) was the dominant reaction course for 9. Therefore, we tried protecting the hydroperoxide functional group of 9 to suppress the fragmentation. ${ }^{19}$ Treatment of 9 with $\mathrm{N}, \mathrm{O}-$ bis-(trimethylsilyl)acetamide (BSA) in $\mathrm{CH}_{2} \mathrm{Cl}_{2}$ gave the corre- sponding bis(trimethylsilylated) product 10 in high yield. Subsequent condensation of $\mathbf{1 0}$ with $\mathbf{5}$ in the presence of $10-20 \%$ $\mathrm{CSA}$ in $\mathrm{CH}_{2} \mathrm{Cl}_{2}$ afforded the desired $\mathbf{2 c}$ (Scheme 2). Trioxane 2a was prepared as previously described. ${ }^{20}$

Trioxepanes $\mathbf{3 a}$ and $\mathbf{3 b}$ were prepared via parallel routes (Scheme 3) beginning with alcohol $\mathbf{1 3}^{21}$ and cinnamyl alcohol (14). The corresponding acetates $(\mathbf{1 5}, \mathbf{1 6})$ underwent successive Co-mediated dioxygenation ${ }^{22}$ and chemoselective reduction to furnish triethylsilyl peroxyalcohols $\mathbf{1 7}$ and $18 .{ }^{23}$ The peroxyalcohols underwent HF-mediated condensation with ketone 5 to produce $\mathbf{3} \mathbf{a}$ and $\mathbf{3} \mathbf{b}$.

In vitro and in vivo antimalarial activities ${ }^{9}$ (Table 1 ) were measured using the chloroquine-resistant $\mathrm{K} 1$ and chloroquinesensitive NF54 strains of Plasmodium falciparum and Plasmodium berghei-infected mice. Several observations arise from the antimalarial data. First, trioxolane $\mathbf{1 b}$ was more than two orders of magnitude less potent than trioxolanes $\mathbf{1 a}$ and $\mathbf{1 c}$. Because it has a $\mathbf{a}-\mathrm{H}$ atom, $\mathbf{1 b}$ may lack the necessary chemical<smiles>CON=Cc1ccccc1</smiles>

4

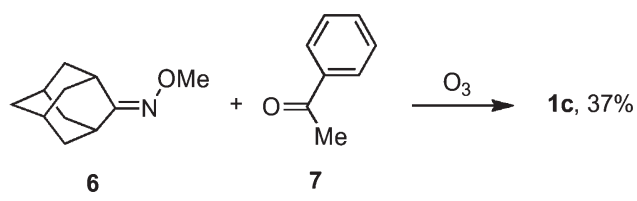

Scheme 1.

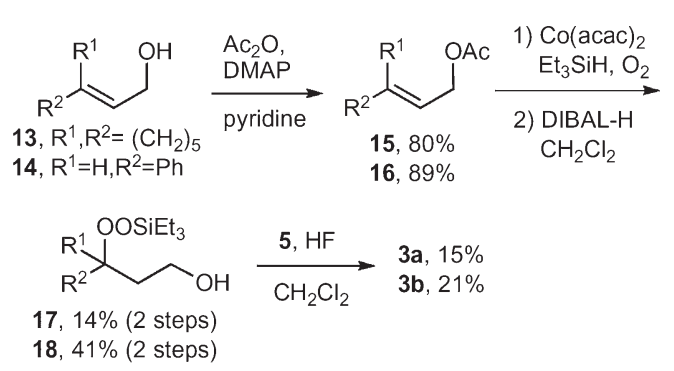

Scheme 3.

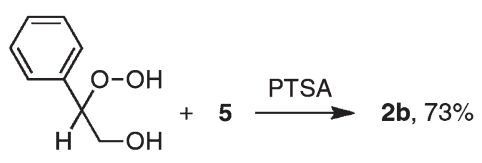

8

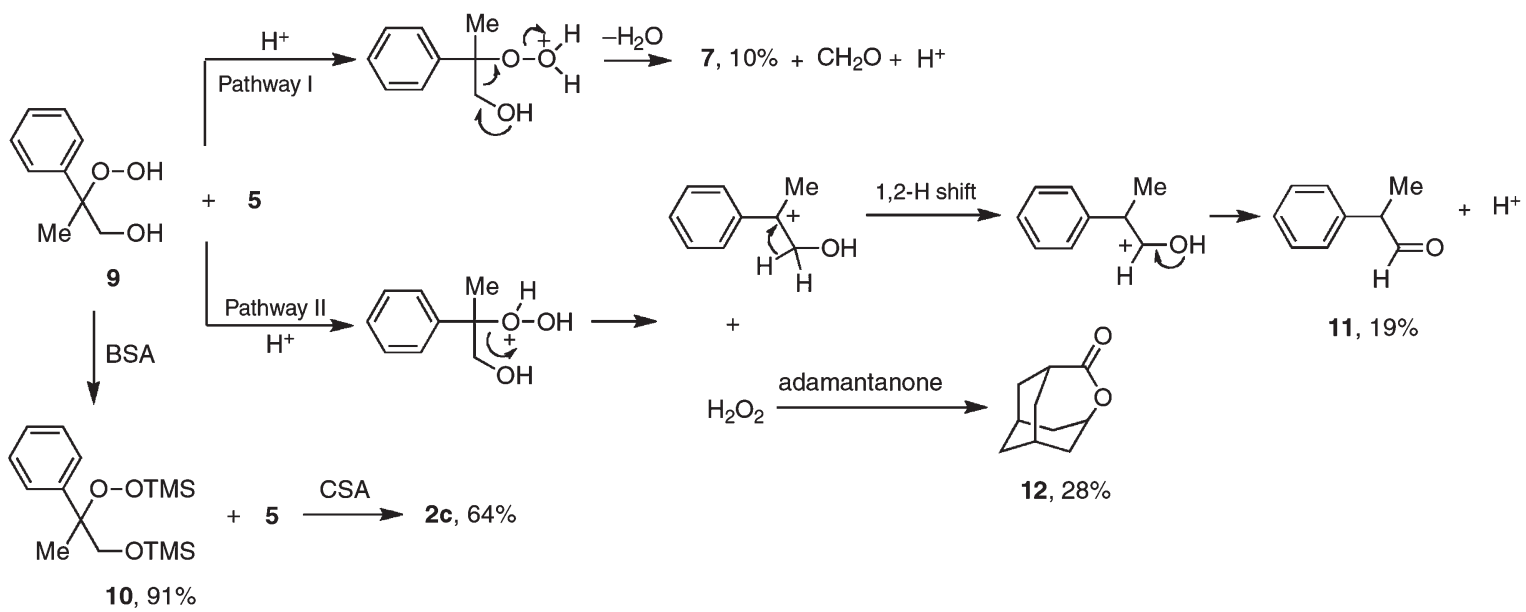

Scheme 2 . 
Table 1. Activity of 1-3 against $P$. falciparum in vitro and $P$. berghei in vivo

\begin{tabular}{|c|c|c|c|}
\hline \multirow[t]{2}{*}{ Compd } & \multicolumn{2}{|c|}{$\mathrm{IC}_{50}(\mathrm{ng} / \mathrm{ml})^{\mathrm{a}}$} & \multirow[t]{2}{*}{ Activityb $^{\mathrm{b}}(\%)$ po } \\
\hline & K1 & NF54 & \\
\hline NONE & - & - & 0 \\
\hline $1 a^{c}$ & 0.97 & 1.4 & $>99.99$ \\
\hline $1 b$ & 400 & $>1000$ & 25 \\
\hline 1c & 2.9 & 3.4 & 99.0 \\
\hline $2 a^{d}$ & 54 & 44 & 0 \\
\hline $2 b$ & 9.1 & 19 & 96 \\
\hline $2 c$ & 19 & 22 & 0 \\
\hline $3 a$ & $\mathrm{ND}^{\mathrm{e}}$ & $>1000$ & 0 \\
\hline $3 b$ & $\mathrm{ND}^{\mathrm{e}}$ & $>1000$ & $\mathrm{ND}^{\mathrm{e}}$ \\
\hline $\mathrm{ART}^{\mathrm{c}, \mathrm{f}}$ & 1.6 & 2.8 & 98 \\
\hline
\end{tabular}

a Mean from $n=2-3$ against chloroquine-resistant (K1) and chloroquinesensitive (NF54) strains of $P$. falciparum.

b Groups of three P. berghei-infected NMRI mice were treated orally one day post-infection with trioxolanes $(100 \mathrm{mg} / \mathrm{kg})$ dissolved or suspended in 3\% ethanol and 7\% Tween 80 . Antimalarial activity was measured by percent reduction in parasitemia on day 3 post-infection. Individual measurements generally differed by less than $10 \%$.

${ }^{\mathrm{c}}$ Data from Dong et al. ${ }^{15}$

d Data from Tang et al. ${ }^{20}$

${ }^{\mathrm{e}}$ Not determined

${ }^{\mathrm{f}} \mathrm{ART}=$ artemisinin

stability $^{24}$ required for antimalarial activity. This contrasts with the good antimalarial activity of the corresponding and presumably more chemically stable trioxane $\mathbf{2 b}$. Trioxanes $\mathbf{2 a}$ and $2 \mathrm{c}$ were less potent than the corresponding trioxolanes $\mathbf{1 a}$ and 1c; neither $\mathbf{2 a}$ nor $\mathbf{2 c}$ had any activity in vivo. The less accessible peroxide bond in the trioxane vs trioxolane heterocy$\mathrm{cle}^{20}$ may explain why trioxanes $\mathbf{2 a}$ and $\mathbf{2} \mathbf{c}$ are less active than their trioxolane chemical cousins $1 \mathbf{a}$ and 1c. Similarly, the complete lack of activity of trioxepanes $\mathbf{3 a}$ and $\mathbf{3} \mathbf{b}$ may arise from peroxide bonds that are too sterically hindered (vide infra). These data suggest that antimalarial activity for these spiroadamantyl trioxolanes, trioxanes, and trioxepanes depends on a finely tuned balance between peroxide bond shielding and accessibility. To provide mechanistic insight into this hypothesis, we examined the reactivity of several of these compounds with iron(II) in the form of $\mathrm{FeSO}_{4}$ and heme.

The reactivity of 1-3 with inorganic ferrous iron was determined using previously established standardized conditions. ${ }^{25}$ In these experiments, pseudo-first order reaction rate constants for $\mathbf{1} \mathbf{b}, \mathbf{2} \mathbf{a}, \mathbf{2} \mathbf{b}, \mathbf{3} \mathbf{a}$, and $\mathbf{3 b}(0.03 \mathrm{mM})$ with $\mathrm{FeSO}_{4}$ $(3 \mathrm{mM})$ in $50 \%$ acetonitrile/water at $37{ }^{\circ} \mathrm{C}$ under an argon atmosphere were determined. These data $(n=3)$ were corrected for non-specific degradation in iron-free controls. Under these experimental conditions, the previously determined pseudo-first order rate constants $(k)$ for $\mathbf{1 a}$ and artemisinin were $0.41 \pm 0.02 \mathrm{~h}^{-126}$ and $0.054 \pm 0.006 \mathrm{~h}^{-1} .{ }^{25}$ The weakly active $1 \mathrm{~b}$ reacted considerably more rapidly $\left(k=1.77 \pm 0.06 \mathrm{~h}^{-1}\right)$ with iron(II) than did 1a confirming our previous observations $^{26-27}$ that chemically reactive peroxides do not necessarily possess high antimalarial activities. Trioxane $2 \mathbf{b}$ reacted with iron(II) at a rate $\left(k=0.12 \pm 0.03 \mathrm{~h}^{-1}\right)$ between that of $\mathbf{1 a}$ and artemisinin, whereas trioxepane $3 \mathbf{b}$ reacted much more slowly $\left(k=0.021 \pm 0.006 \mathrm{~h}^{-1}\right)$, and neither 2a nor 3a underwent statistically significant degradation over the $24 \mathrm{~h}$ time course studied $\left(k=0.011 \pm 0.013 h^{-1}\right.$ and $0.017 \pm 0.012 h^{-1}$, respectively).

As has been previously demonstrated for $\mathbf{1 a}$ versus $2 \mathbf{a}^{20}$ the difference in iron-mediated reactivity between $1 \mathbf{a}$ and $\mathbf{3 a}$

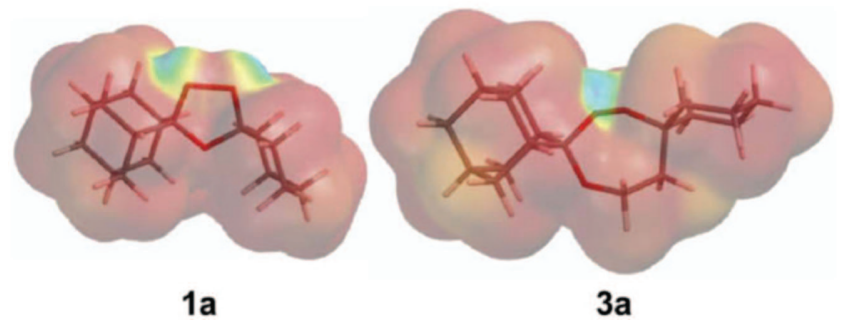

Figure 3. LUMO (blue) mapped on isodensity surfaces of 1a and 3a.

can be explained by considering peroxide bond accessibility of the more reactive equatorial peroxide bond conformers ${ }^{28}$ as determined by molecular modeling (Spartan'08, Wavefunction, Inc.). As shown in Figure 3, the peroxide bond LUMO in 1a is easily accessible from the cyclohexane side, whereas the peroxide bond LUMO in $\mathbf{3 a}$ is not accessible from either direction, consistent with the low reactivity of 3a with iron(II). The greater steric crowding in $\mathbf{3} \mathbf{a}$ is due to the methylene groups of the trioxepane ring decreasing the angle between the adamantane and cyclohexane rings. This lack of iron-mediated reactivity for trioxepane $\mathbf{3 a}$ is consistent with its lack of antimalarial activity; similar arguments have been put forth to explain the low antimalarial activity of other sterically congested 1,2,4-trioxepanes. ${ }^{29}$

We have previously shown ${ }^{30}$ a good correlation between in vitro antimalarial activity and heme alkylation efficiency for a series of 22 trioxolanes. We measured the efficiency of heme alkylation for these trioxolanes, trioxanes and trioxepanes using these same experimental conditions. ${ }^{30}$ Significant heme alkylation was observed within $30 \mathrm{~s}$ for the active 1c $(67 \pm 2 \%)$ and moderately active $2 \mathbf{b}(55 \pm 4 \%)$, and to a slightly lesser extent for the less active $\mathbf{1 b}(50 \pm 1 \%)$ and $\mathbf{2 a}(45 \pm 1 \%)$; however the extent of heme alkylation by these compounds was far lower than previously reported for the highly active trioxolanes 1a $(86 \pm 0.2 \%)$ and OZ277 $(83 \pm 2 \%) .{ }^{30}$ Trioxepanes $3 \mathbf{a}$ and $\mathbf{3 b}$ mediated very little heme alkylation $(25 \pm 1 \%$ and $1 \pm 0.4 \%)$, in agreement with their lack of antimalarial activity. The investigation of heme alkylation appears to give a more accurate prediction of antimalarial activity than investigation of iron-mediated reaction rates, suggesting that antimalarial activity is not merely dependant on peroxide bond cleavage, but also on the ability of reactive intermediates to alkylate heme or other proximal targets. This further supports a likely role for heme alkylation in the antimalarial mechanism of action of peroxide antimalarials. ${ }^{6}$

Acknowledgments - We thank Josefina Santo Tomas and Christopher Snyder for assistance in performing the in vivo antimalarial assays. This investigation received financial support from Medicines for Malaria Venture (MMV).

\section{References \& notes}

1. N. J. White, Science 320 (2008), p. 330.

2. C. W. Jefford, Curr. Med. Chem. 8 (2001), p. 1803.

3. S. R. Meshnick, Int. J. Parasitol. 32 (2002), p. 1655.

4. P. M. O'Neill and G. H. Posner, J. Med. Chem. 47 (2004), p. 2945.

5. M. Kaiser, S. Wittlin, A. Nehrbass-Stuedli, Y. Dong, X. Wang, A. Hemphill, H. Matile, R. Brun, and J. L. Vennerstrom, Antimicrob. Agents Chemother. 51 (2007), p. 2991.

6. A. Robert, F. Benoit-Vical, C. Claparols, and B. Meunier, Proc. Natl. Acad. Sci. U.S.A. 102 (2005), p. 13676. 
7. D.A. Casteel, S.P. Peri, and L. Gerena, Bioorg. Med. Chem. Lett. 3 (1993), p. 1707.

8. Y. Tang, Y. Dong, and J. L. Vennerstrom, Med. Res. Rev. 24 (2004), p. 425.

9. J. L. Vennerstrom, S. Arbe-Barnes, R. Brun, S. A. Charman, F. C. K. Chiu, J. Chollet, Y. Dong, A. Dorn, D. Hunziker, H. Matile, K. McIntosh, M. Padmanilayam, J. Santo Tomas, C. Scheurer, B. Scorneaux, Y. Tang, H. Urwyler, S. Wittlin, and W. N. Charman, Nature 430 (2004), p. 900.

10. Adamantane-2-spiro-3'-5'-phenyl-1',2',4'-trioxolane (1b): ${ }^{11}{ }^{1} \mathrm{H}$ NMR $\left(500 \mathrm{MHz}, \mathrm{CDCl}_{3}\right) \delta 1.70-1.93(\mathrm{~m}, 9 \mathrm{H}), 2.03-2.16(\mathrm{~m}, 4 \mathrm{H}), 2.22-$ $2.26(\mathrm{~m}, 1 \mathrm{H}), 6.09(\mathrm{~s}, 1 \mathrm{H}), 7.36-7.46(\mathrm{~m}, 3 \mathrm{H}), 7.50-7.56(\mathrm{~m}, 2 \mathrm{H}) .{ }^{13} \mathrm{C}$ NMR $\left(125.7 \mathrm{MHz}, \mathrm{CDCl}_{3}\right) \delta 26.5,26.8,34.2,34.6,34.9,35.7,35.8$, 36.78, 36.8, 103.7, 113.0, 127.9, 128.5, 130.3, 132.8. Anal. Calcd for $\mathrm{C}_{17} \mathrm{H}_{20} \mathrm{O}_{3}: \mathrm{C}, 74.97 ; \mathrm{H}, 7.40$. Found: C, 74.94; H, 7.19. Adamantane2-spiro-3'-5'-methyl-5'-phenyl-1',2',4'-trioxolane (1c): mp 70-72 ${ }^{\circ} \mathrm{C}$. ${ }^{1} \mathrm{H}$ NMR $\left(500 \mathrm{MHz}, \mathrm{CDCl}_{3}\right) \delta 1.72(\mathrm{~s}, 3 \mathrm{H}), 1.56-2.20(\mathrm{~m}, 14 \mathrm{H}), 7.28-$ $7.38(\mathrm{~m}, 3 \mathrm{H}), 7.50-7.56(\mathrm{~m}, 2 \mathrm{H}) .{ }^{13} \mathrm{C}$ NMR $\left(125.7 \mathrm{MHz}, \mathrm{CDCl}_{3}\right) \delta$ 25.9, 26.5, 26.9, 34.5, 34.75, 34.78, 35.3, 35.4, 36.6, 36.8, 108.7, 112.9, 125.2, 128.06, 128.11, 142.6. Anal. Calcd for $\mathrm{C}_{18} \mathrm{H}_{22} \mathrm{O}_{3}: \mathrm{C}, 75.50 ; \mathrm{H}$, 7.74. Found: C, 75.58; H, 7.63. Adamantane-2-spiro-3'-6'-phenyl$1^{\prime}, 2^{\prime}, 4^{\prime}$-trioxane (2b): mp 110-111 ${ }^{\circ} \mathrm{C} .{ }^{1} \mathrm{H}$ NMR $\left(500 \mathrm{MHz}, \mathrm{CDCl}_{3}\right) \delta$ $1.60-2.16(\mathrm{~m}, 13 \mathrm{H}), 3.07(\mathrm{br}, \mathrm{s}, 1 \mathrm{H}), 3.83\left(\mathrm{dd}, J_{1}=12 \mathrm{~Hz}, J_{2}=3.5 \mathrm{~Hz}\right.$, $1 \mathrm{H}), 4.12\left(\mathrm{dd}, J_{1}=12 \mathrm{~Hz}, J_{2}=10.5 \mathrm{~Hz}, 1 \mathrm{H}\right), 5.30\left(\mathrm{dd}, J_{1}=10.5 \mathrm{~Hz}\right.$, $\left.\mathrm{J}_{2}=3.5 \mathrm{~Hz}, 1 \mathrm{H}\right), 7.30-7.40(\mathrm{~m}, 5 \mathrm{H}) .{ }^{13} \mathrm{C} \mathrm{NMR}\left(125.7 \mathrm{MHz}, \mathrm{CDCl}_{3}\right)$ $\delta$ 27.16, 27.17, 29.4, 33.0, 33.3, 33.5, 33.7, 36.3, 37.2, 62.7, 81.3, 104.5, 127.3, 128.7, 129.1, 135.3. Anal. Calcd for $\mathrm{C}_{18} \mathrm{H}_{22} \mathrm{O}_{3}$ : C, 75.50; $\mathrm{H}$, 7.74. Found: C, 75.76; H, 7.60; Adamantane-2-spiro-3'-6'-methyl6'-phenyl-1',2',4'-trioxane (2c): mp 61-62 ${ }^{\circ} \mathrm{C},{ }^{1} \mathrm{H}$ NMR $(500 \mathrm{MHz}$, $\left.\mathrm{CDCl}_{3}\right) \delta 1.44-2.04$ (br m, 16H), 3.02 (br s 1H), 3.75 (br s $\left.1 \mathrm{H}\right), 4.16$ (br s 1H), 7.25-7.60 (m, 5H), ${ }^{13} \mathrm{C}$ NMR $\left(125.7 \mathrm{MHz}, \mathrm{CDCl}_{3}\right) \delta 21.9$ (br), 25.4 (br), 27.14, 27.17 (br), 29.7 (br), 33.2 (br), 33.3, 33.5, 36.2 (br), 37.2, 65.7 (br), 79.8 (br), 104.4, 124.7 (br), 127.6 (br), 128.3, 141.6 (br). Anal. Calcd for $\mathrm{C}_{19} \mathrm{H}_{24} \mathrm{O}_{3}$ : C, 75.97; H, 8.05. Found: C, 76.16; $\mathrm{H}$, 8.24; Adamantane-2-spiro-3'-7'-cyclohexyl-1',2',4'-trioxepane (3a): ${ }^{1} \mathrm{H}$ NMR $\left(400 \mathrm{MHz}, \mathrm{CDCl}_{3}\right) \delta 1.30-1.86(20 \mathrm{H}), 1.89-2.02(\mathrm{~m}$, $3 \mathrm{H}), 2.02-2.15(\mathrm{~m}, 2 \mathrm{H}), 2.40($ br s, $1 \mathrm{H}), 3.69\left(\mathrm{dt}, \mathrm{J}_{\mathrm{Ha}}=3.7, J_{\mathrm{Hb}}=3.7\right.$, $1 \mathrm{H}), 3.69(\mathrm{dt}, J=12.4,3.7,1 \mathrm{H}), 3.90$ (apparent pentet, $J=6.2$, probably dt, $J=12.2,6.2,1 \mathrm{H}),{ }^{13} \mathrm{C}$ NMR $\left(100.6 \mathrm{MHz} \mathrm{CDCl}_{3}\right) \delta 22.0,22.4$, 26.0, 27.3, 32.9, 33.6, 33.7, 33.8, 33.9, 34.2, 34.6, 35.7, 37.5, 42.3, 58.1, 81.7, 107.5, HRMS-FAB calcd for $\mathrm{C}_{18} \mathrm{H}_{29} \mathrm{O}_{3}\left(\mathrm{MH}^{+}\right)$: 293.2117; found 293.2103. Adamantane-2-spiro-3'-7'-phenyl-1',2',4'-trioxepane (3b): ${ }^{1} \mathrm{H}$ NMR $\left(400 \mathrm{MHz}, \mathrm{CDCl}_{3}\right) \delta 1.59-1.75(\mathrm{~m}, 6 \mathrm{H}), 1.79-1.86(\mathrm{~m}, 2 \mathrm{H})$, $1.89-2.14(\mathrm{~m}, 6 \mathrm{H}), 2.22-2.42(\mathrm{~m}, 2 \mathrm{H}), 3.85(\mathrm{dt}, J=12.2,3.4,1 \mathrm{H})$, 4.13 (app t, $J=11.3,1 \mathrm{H}), 5.14(\mathrm{dd}, J=11.5,3.5,1 \mathrm{H}), 7.29-7.40(\mathrm{~m}$, $5 \mathrm{H}),{ }^{13} \mathrm{C}$ NMR $\left(75.5 \mathrm{MHz}, \mathrm{CDCl}_{3}\right) \delta 27.1,27.2,33.1,33.6,33.9,34.1$, 34.7, 35.0, 37.5, 39.4, 60.0, 76.6, 86.1, 108.6, 127.3, 128.4, 128.5, 138.5, HRMS-FAB calc for $\mathrm{C}_{19} \mathrm{H}_{25} \mathrm{O}_{3}\left(\mathrm{MH}^{+}\right)$: 301.1804; found 301.1809.
11. H. Keul, Chem. Ber. 108 (1975), p. 1207.

12. K. Griesbaum, X. Liu, A. Kassiaris, and M. Scherer, Liebigs Ann. Recl. (1997), p. 1381.

13. T. Konakahara, M. Matsuki, S. Sugimoto, and K. Sato, J. Chem. Soc., Perkin Trans. 1 (1987), p. 1489.

14. Y. Dong and J. L. Vennerstrom, J. Org. Chem. 63 (1998), p. 8582.

15. Y. Dong, J. Chollet, H. Matile, S. A. Charman, F. C. K. Chiu, W. N. Charman, B. Scorneaux, H. Urwyler, J. Santo Tomas, C. Scheurer, C. Snyder, A. Dorn, X. Wang, J. M. Karle, Y. Tang, S. Wittlin, R. Brun, and J. L. Vennerstrom, J. Med. Chem. 48 (2005), p. 4953.

16. Y. Ogata, Y. Sawaki, and H. Shimizu, J. Org. Chem. 43 (1978), p. 1760.

17. J. Kagan and J. T. Przybytek, Tetrahedron 29 (1973), p. 1163.

18. M. S. Kharasch, A. Fono and W. Nudenberg, J. Org. Chem. 15 (1950), p. 748.

19. H.-S. Kim, K. Tsuchiya, Y. Shibata, Y. Wataya, Y. Ushigoe, M. Araki, M. Nojima, and K. J. McCullough, J. Chem. Soc., Perkin Trans. 1 (1999), p. 1867.

20. Y. Tang, Y. Dong, X. Wang, K. Sriraghavan, J. K. Wood, and J. L. Vennerstrom, J. Org. Chem. 70 (2005), p. 5103.

21. Z. Bourhani and A. Malkov, Chem. Commun. (2005), p. 4592.

22. T. Tokuyasu, S. Kunikawa, A. Masuyama, and M. Nojima, Org. Lett. 4 (2002), p. 3595.

23. H. Jin, H. Liu, Q. Zhang, and Y. Wu, J. Org. Chem. 70 (2005), p. 4240.

24. N. Kornblum and H. E. DeLaMare, J. Am. Chem. Soc. 73 (1951), p. 880.

25. D. J. Creek, F. C. K. Chiu, R. J. Prankerd, W. N. Charman, and S. A. Charman, J. Pharm. Sci. 94 (2005), p. 1820.

26. D. J. Creek, W. N. Charman, F. C. K. Chiu, R. J. Prankerd, K. J. McCullough, Y. Dong, J. L. Vennerstrom, and S. A. Charman, J. Pharm. Sci. 96 (2007), p. 2945.

27. X. Wang, Y. Dong, S. Wittlin, D. Creek, J. Chollet, S. A. Charman, J. Santo Tomas, C. Scheurer, C. Snyder, and J. L. Vennerstrom, J. Med. Chem. 50 (2007), p. 5840.

28. The equatorial peroxide conformer provides greater access to the peroxide bond from the cyclohexane side. For 1a and 3a, the energy difference between the two chair conformers $\left(\Delta E=E_{e q}-E_{a x}\right)$ is 0.280 and $1.71 \mathrm{kcal} / \mathrm{mol}$, respectively.

29. R. Amewu, A. V. Stachulski, N. G. Berry, S. A. Ward, J. Davies, G. Labat, J.-F. Rossignol, and P. M. O'Neill, Bioorg. Med. Chem. Lett. 16 (2006), p. 6124.

30. D. J. Creek, W. N. Charman, F. C. K. Chiu, R. J. Prankerd, Y. Dong, J. L. Vennerstrom, and S. A. Charman, Antimicrob. Agents Chemother. 52 (2008), p. 1291. 